\title{
Effects of domestic and industrial pollution on distribution and abundance of aquatic oligochaetes in the Forth estuary
}

\author{
D. S. McLusky, M. Teare \& P. Phizacklea \\ Department of Biology, University of Stirling; Stirling, FK9 4LA, Scotland
}

\begin{abstract}
The Forth estuary is a major estuary on the east coast of Scotland; it receives effluent from domestic and industrial (petro-chemical and distilling) sources. Following a study on the distribution of the macrofauna of the intertidal areas in relation to pollution (McLusky et. al., 1978), this paper is concerned with the distribution and abundance of aquatic oligochaetes and the small polychaete Manayunkia aestuarina in relation to estuarine salinity, organic enrichment, and industrial effluent. In the most polluted parts of the estuary oligochaetes are the sole inhabitants of the mudflats; in other less polluted flats they are very abundant. In the least polluted parts the numbers of oligochaetes diminish as the numbers and diversity of macrofauna increase. Estimates of the production of oligochaetes are given.
\end{abstract}

\section{INTRODUCTION}

The Forth estuary is a major estuary on the east coast of Scotland, which extends for over $50 \mathrm{~km}$ from an upstream limit at Stirling to the sea at Edinburgh. The distribution and abundance of the macrobenthic intertidal fauna, principally Hydrobia ulvae (Pennant), Nereis diversicolor O. F. Müller, Macoma balthica (L.), and Cerastoderma edule (L.), in relation to environmental factors and pollutants have been described by McLusky et al. $(1976,1978)$. A historical review of the ecology of the Forth estuary has been given by McLusky (1979). In these earlier studies little attention was paid to the small polychaete and oligochaete worms which also inhabit the intertidal mudflats. Gray (1976) and Warwick et al. (1979) have emphasized the potential importance of such worms as food for wading birds and fish. In this paper the distribution and abundance of oligochaetes and small polychaetes within the intertidal areas of the Forth estuary are described in relation to environmental factors and pollutants.

\section{METHODS}

The investigation has been conducted in two parts. Firstly a study was made in 1977 of the oligochaetes in the intertidal areas of the Forth estuary between Stirling and Kincardine Bridge, and secondly a study of the oligochaetes and small polychaetes was made in 1979 in the larger intertidal area between Kincardine Bridge and Bo'ness (Fig. 1). For the former study 8 stations were sampled in June, July, September and November 1977; on each occasion, two $5-\mathrm{cm}^{3}$ cores were collected. Each sample was passed 


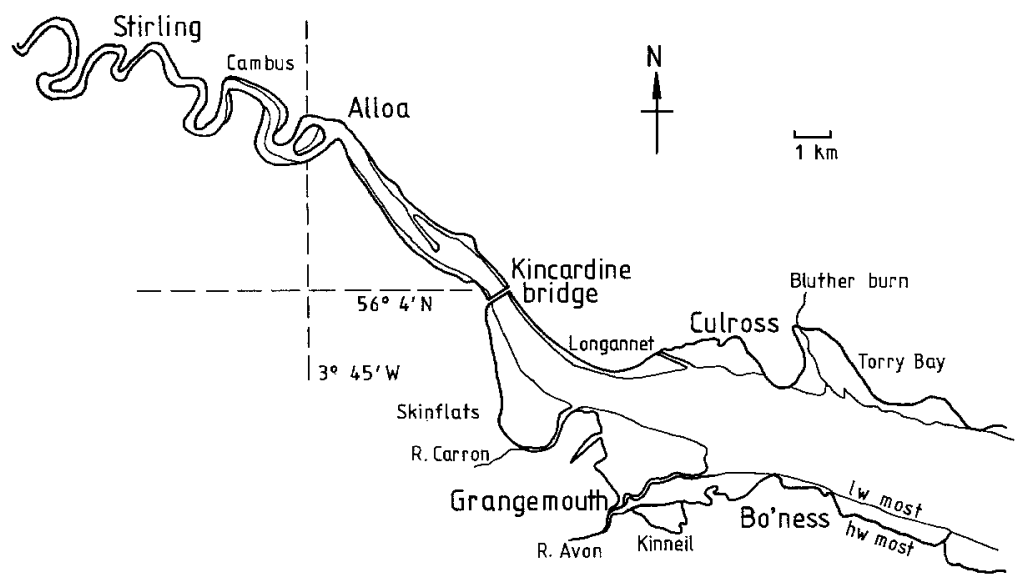

Fig. 1. Estuary of the Firth of Forth, Scotland, showing place names mentioned in the text

through a $0.25-\mathrm{mm}$ sieve, and preserved in $4 \%$ formaldehyde solution. The sieved samples were examined under the microscope, and all animals present removed and identified; a random sample was measured and weighed on a Beckman microbalance after having been dried at $60^{\circ} \mathrm{C}$. The interstitial salinity (expressed as $\% 0 \mathrm{NaCl}$ ) was determined for each station at each sampling.

For the second part of the study, 28 stations at Culross, Torry Bay, Kinneil and Skinflats were sampled during March 1979. At each station three samples were collected with a core tube of $8 \mathrm{~cm}^{2}$, to a depth of $5 \mathrm{~cm}$, and placed directly into $4 \%$ formaldehyde solution, made up with sea water. For 5 stations at Kinneil a piston corer of $11 \mathrm{~cm}^{2}$ was used. Samples were passed through a $0.125-\mathrm{mm}$ sieve to remove fine particles and the sediment retained was washed into beakers. Ludox TM (Du Pont) diluted to a SG of 1.10 with water was added, and after allowing the sediment to settle the supernatant liquid was decanted through a $0.125-\mathrm{mm}$ mesh sieve to collect the animals. The decantation was repeated two more times and the extraction efficiency was found to be over $96 \%$. Worms from one sample at each station were identified, counted, dried to constant weight for $48 \mathrm{~h}$ at $60^{\circ} \mathrm{C}$ and weighed on a Mettler HL 52 balance. Worms that could not be identified to species using a binocular microscope were weighed together as an "other sp." category. Animals in this category from another sample were placed in Ammans lactophenol on microscope slides prior to identification using a compound microscope. The ratio of each species identified from the "other sp." category was then used to compute the numbers and weight of each species at that station. The numbers and biomass per $\mathrm{m}^{2}$ of each species at each station were computed and the mean number and biomass per $\mathrm{m}^{2}$ calculated by dividing the total for each species by the number of stations sampled.

\section{RESULTS}

The mean numbers and biomass of each species for the two parts of the study are presented in Tables 1 and 2. In Figure 2 the abundance of the principal species is presented in relation to their position along the length of the estuary. Stations are referred to in terms of $\mathrm{km}$ from Stirling, which is the upper limit of tidal range on the 
Forth estuary. The upper part of the estuary $(0-16 \mathrm{~km}$, Stirling - Cambus) is predominantly fresh-water, with the interstitial salinity ranging from $0.2 \% \mathrm{NaCl}$ at Stirling to a maximum of $4.1 \%$ at Cambus. In this part of the estuary the sole intertidal inhabitants were the oligochaetes Tubifex tubifex and Limnodrilus hoffmeisteri. Large numbers and biomasses of these two species were recorded with a maximum at the $10-\mathrm{km}$ station where the mean numbers were $127,400 \mathrm{~m}^{-2}$ for $T$. tubifex and $105,800 \mathrm{~m}^{-2}$ for $L$. hoffmeisteri, and the mean biomasses were 57.663 and $22.154 \mathrm{~g}$ dry wt $\mathrm{m}^{-2}$ respectively. Between 16 and $18 \mathrm{~km} T$. tubifex and $L$. hoffmeisteri were replaced by $T$. costatus and Peloscolex benedeni. The interstitial salinity in this area ranges from $1.6 \%$ to a

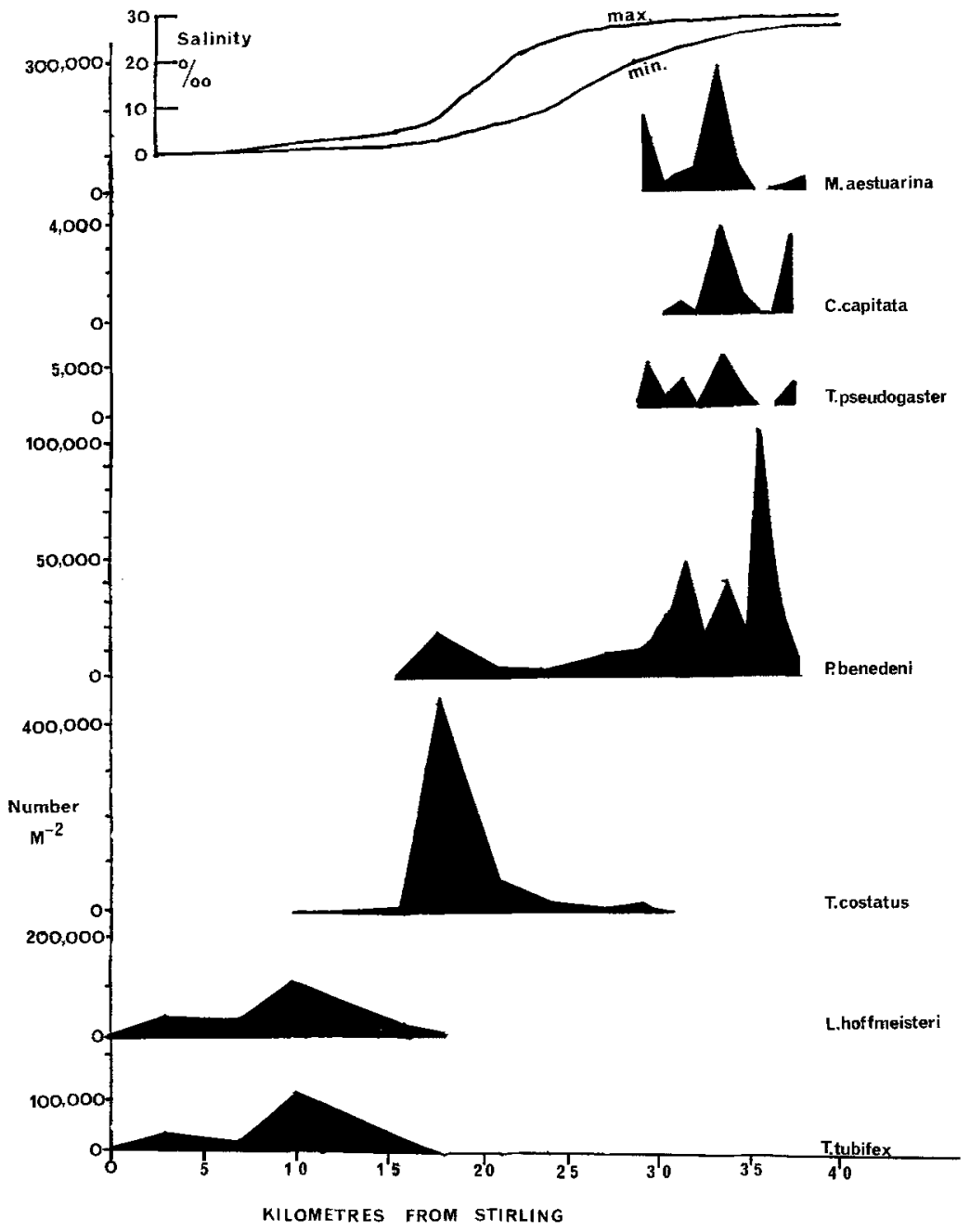

Fig. 2. Distribution of the oligochaetes Tubifex tubifex, Limnodrilus hoffmeisteri, Tubifex costatus, Peloscolex benedeni, Tubifex pseudogaster and the polychaetes Capitella capitata and Manayunkia aestuarina in relation to distance down the Forth estuary, measured as kilometres below Stirling, which is the upper tidal limit. Abundance is presented as mean number $\mathrm{m}^{-2}$. The maximum and minimum interstitial salinity at stations along the estuary is also presented 
Table 1. Mean numbers and biomass of oligochaete species recorded from the intertidal estuarine Firth of Forth between Stirling and Kincardine Bridge in 1977 (8 stations, 0-28 km from Stirling)

\begin{tabular}{|lccc|}
\hline Species & $\begin{array}{c}\text { Mean numbers } \\
(\text { nos m-2) }\end{array}$ & $\begin{array}{c}\text { Mean biomass } \\
\text { (g dry wt } \mathrm{m}^{-2} \text { ) }\end{array}$ & $\begin{array}{c}\text { Number of } \\
\text { stations at } \\
\text { which recorded }\end{array}$ \\
\hline Tubifex tubifex (Müller) & 25175 & 11.415 & 4 \\
Limnodrilus hoffmeisteri Claparède & 27015 & 5.140 & 5 \\
Tubifex costatus Claparède & 63867 & 11.309 & 5 \\
Peloscolex benedeni (Udekem) & 2679 & 0.110 & 4 \\
Total & 118736 & 27.975 & - \\
\hline
\end{tabular}

Table 2. Mean numbers and biomass of oligochaete and polychaete species recorded from the intertidal estuarine Firth of Forth between Kincardine Bridge and Bo'ness in March 1979 (28 stations, 28-38 km from Stirling)

\begin{tabular}{|c|c|c|c|}
\hline Species & $\begin{array}{l}\text { Mean numbers } \\
\left(\text { (nos } \mathrm{m}^{-2}\right)\end{array}$ & $\begin{array}{l}\text { Mean biomass } \\
\left(\mathrm{g} \text { dry wt } \mathrm{m}^{-2} \text { ) }\right.\end{array}$ & $\begin{array}{c}\text { Number of } \\
\text { stations at } \\
\text { which recorded }\end{array}$ \\
\hline \multicolumn{4}{|l|}{ Oligochaeta } \\
\hline Tubifex costatus Claparède & 1130 & 0.060 & 4 \\
\hline T. pseudogaster (Dahl)* & 1721 & 0.109 & 13 \\
\hline Peloscolex benedeni (Udekem) ${ }^{*}$ & 19894 & 3.629 & 25 \\
\hline Amphichaeta sannio Kallstenius & 4570 & 0.029 & 12 \\
\hline Paranais litoralis (Muller) & 374 & 0.021 & 7 \\
\hline Lumbricillus lineatus? Muller & 267 & 0.010 & 1 \\
\hline Enchytraid sp. & 113 & 0.008 & 1 \\
\hline \multicolumn{4}{|l|}{ Polychaeta } \\
\hline Capitella capitata (Fabricius) & 2693 & 0.134 & 8 \\
\hline Cirratulus cirratus (Muller) & 326 & 0.060 & 4 \\
\hline Manayunkia aestuarina (Bourne) & 110593 & 2.206 & 22 \\
\hline Pygospio elegans Claparède & 512 & 0.034 & 8 \\
\hline Polychaeta sp. & 133 & 0.004 & 1 \\
\hline Total & 141952 & 6.304 & - \\
\hline
\end{tabular}

maximum of $7.7 \%$. T. costatus was the dominant oligochaete from $18 \mathrm{~km}$ (Cambus) to 30 $\mathrm{km}$, with a maximum mean abundance of $444,933 \mathrm{~m}^{-2}$ at $18 \mathrm{~km}$, representing a mean biomass of $78.044 \mathrm{~g}$ dry wt $\mathrm{m}^{-2}$.

Peloscolex benedeni was present in the Forth downstream from a point $18 \mathrm{~km}$ from Stirling onwards, but between $18-30 \mathrm{~km}$ from Stirling $T$. costatus was numerically dominant, and $P$. benedeni here only reached a mean abundance of $2679 \mathrm{~m}^{-2}$. Below Kincardine Bridge $(28 \mathrm{~km}) T$. costatus numbers diminished until it was no longer present below $30 \mathrm{~km}$, whilst $P$. benedeni numbers increased to a mean abundance of $19,894 \mathrm{~m}^{-2}$ 
representing $3.629 \mathrm{~g}$ dry $\mathrm{wt} \mathrm{m}^{-2}$. The most abundant $P$. benedeni populations were at 36 $\mathrm{km}$ from Stirling with $100,000 \mathrm{~m}^{-2}$ representing $13.0 \mathrm{~g}$ dry wt $\mathrm{m}^{-2}$. The second most abundant oligochaete below Kincardine Bridge was Amphichaeta sannio with a mean abundance of $4570 \mathrm{~m}^{-2}$. These animals were however very small and this number only represents $0.029 \mathrm{~g}$ dry $\mathrm{wt} \mathrm{m}^{-2}$. The second most important oligochaete in this area in terms of biomass was the larger Tubifex pseudogaster at $0.109 \mathrm{~g}$ dry wt $\mathrm{m}^{-2}$. Other oligochaetes (Paranais litoralis, Lumbricillus lineatus and Enchytraid sp.) were all less than $0.03 \mathrm{~g}$ dry wt $\mathrm{m}^{-2}$.

No small polychaetes were recorded between Stirling and Kincardine Bridge (0-28 $\mathrm{km}$ ); however below Kincardine Bridge large numbers of Manayunkia aestuarina occurred with a maximum of $281,254 \mathrm{~m}^{-2}$ at $33 \mathrm{~km}$, representing a biomass of $6.274 \mathrm{~g}$ dry wt $\mathrm{m}^{-2}$. Capitella capitata was present at the Kinneil area $(33-37 \mathrm{~km})$ with a maximum of $3809 \mathrm{~m}^{-2}$ at $33 \mathrm{~km}$, representing $0.287 \mathrm{~g}$ dry wt $\mathrm{m}^{-2}$. Cirratulus cirratus was restricted to the Culross/Torry Bay area, and Pygiospio elegans was thinly scattered throughout the area. The full data from individual sampling stations are tabulated in Phizacklea (1978) and Teare (1979).

\section{DISCUSSION}

The Forth estuary can be conveniently divided into two areas, a narrow upper estuary from Stirling to Kincardine Bridge (0-28 km from Stirling) where the interstitial salinity ranges from 0 to $26 \%$, and a broad lower estuary from Kincardine Bridge to the sea where the interstitial salinity is greater than $26 \%$ (Fig. 1). The sampling programme and the results reflect this difference.

In the first $16 \mathrm{~km}$ the estuary, although tidal, is dominated by fresh-water conditions. Over the first $10 \mathrm{~km}$ the interstitial salinity is always less than $1 \%$, at $10 \mathrm{~km}$ it is between 1.0 and $1.9 \%$, and at $16 \mathrm{~km}$ it is between 1.6 and $4.1 \%$. The intertidal fauna was found to be exclusively the fresh-water oligochaetes $T$. tubifex and $L$. hoffmeisteri. Stczynska-Jurewicz (1972) found that the maximum salinity at which $T$. tubifex could survive was $9 \%$ and the maximum at which natural egg laying and development occurred was $4 \%$. Kennedy (1965) stated that salinity controlled the distribution of $L$. hoffmeisteri, but did not give precise limits. In the present study $T$. tubifex was found in localities with a maximum salinity of $4.1 \%$, and $L$. hoffmeisteri has occurred at salinities of up to $7.7 \%$, confirming the limits noted above. This stretch of the Forth is subject to organic pollution, and it may be noted that maximum numbers and biomass occurred at the $10-\mathrm{km}$ station which is downstream of the discharge from Stirling sewage works. Brinkhurst (1965) noted that in fresh-water enviroments these two species were the last species to remain when pollution became severe, and Eyres et al. (1978) noted that these 2 species reached their greatest numbers in the organically polluted stretches of the River Irwell.

Between 16 and $28 \mathrm{~km}$ the interstitial salinity increases progressively from a mean of $3.2 \%$ to a mean of $26.4 \%$. Over this stretch of the estuary the dominant oligochaete was T. costatus. Maximum biomass and numbers were reported at $18 \mathrm{~km}$ from Stirling which is an area which receives large volumes of effluent from whisky distilling industries as well as domestic effluent. This area experiences marked oxygen depletion (Stout, 1976; Forth River Purification Board, 1978), which results in an absence of all fauna except 
oligochaetes. It is evident however that $T$. costatus was thriving in this environment. Twenty-one $\mathrm{km}$ from Stirling other macrobenthic animals occurred in the mudflats, especially Nereis diversicolor and Corophium volutator (McLusky et al., 1978). From the data on salinity it might have been expected that these two species could have lived as far upstream as $16 \mathrm{~km}$; however the organic pollution and oxygen depletion in the 16-21 $\mathrm{km}$ region of the estuary has excluded these macrobenthic animals, whilst permitting $T$. costatus to thrive.

Peloscolex benedeni was present in the Forth estuary from $18 \mathrm{~km}$ from Stirling onwards. Numbers remained low, however, until beyond Kincardine Bridge $(29 \mathrm{~km})$, as in the $18-29 \mathrm{~km}$ section it was overshadowed by $T$. costatus. The estuarine succession of $T$. tubifex and L. hoffmeisteri, then $T$. costatus, then $P$. benedeni, was also found by Hunter and Arthur (1978) in the Thames estuary.

In the lower part of the estuary (29 km from Stirling onwards) $P$. benedeni became the dominant oligochaete in the estuary, and together with the polychaete Manayunkia aestuarina accounted for $92 \%$ of the biomass of small worms in the large intertidal mudflats which characterise this part of the estuary (Fig. 1). The mudflats of this area $(30-38 \mathrm{~km})$ comprise $65 \%$ of the total intertidal area of the Forth estuary, and are recognised as the main birdfeeding areas in the estuary (McLusky et al. 1976). $P$. benedeni was widely spread in this area, being present at 25 out of 28 stations sampled. The only stations from which it was absent were 2 stations situated within $1 / 2 \mathrm{~km}$ of the effluent from the Grangemouth petro-chemical complex, and 1 station on the sandy part of Torry Bay. The absence of $P$. benedeni from sandy sediments is in agreement with the observations of Wharfe (1975) at the Isle of Grain. Leppäkoski (1975) noted in Saltkalle Fjord that $P$. benedeni could only tolerate slight pollution, but expanded both in area and quantitatively with an increasing degree of pollution. In the present study its absence from the most polluted parts of the Kinneil mudflats, coupled with its abundance in the less polluted areas would confirm this observation. Pearson \& Rosenberg (1978) have reviewed benthic succession in relation to organic enrichment, and point to $P$. benedeni as being the most conspicuous oligochaete in the polluted parts of the Gothenburg estuary. They also list many records of $P$. benedeni being abundant in polluted localities, especially on the edge of abiotic zones. This part of the Forth estuary is polluted by petro-chemical industries, sewage discharge, and discharge from the polluted Rivers Carron and Avon. The widespread distribution and abundance of $P$. benedeni in all except abiotic environments emphasises the impact of pollution in this part of the Forth estuary.

The small size of Amphichaeta sannio reduced its importance in biomass terms and probably helps to explain the paucity of records for this species. It has been recorded from Danish fjords and estuaries (Dahl, 1960; Muus, 1967), and the Baltic (Laasko, 1969) but this appears to be the first British record. Paranais litoralis is another common estuarine oligochaete but has quite a patchy distribution on the Forth and was never recorded in very large numbers.

The most important polychaete in the Forth was the common estuarine species Manayukia aestuarina which - with a wide distribution and high biomass - was second in importance to $P$. benedeni. This species was first observed in the Forth in January 1979 (observed by authors) and it was not certain whether it had previously been overlooked or was a genuine new species. In view of the wide distribution and large 
numbers it appears more likely that the sampling methods used previously had not collected this fairly small animal. $M$. aestuarina reached maximum numbers at $33 \mathrm{~km}$ from Stirling close to a domestic sewage outfall but it is interesting that the numbers were lower and the animal dry weight significantly lower on Skinflats $(29-30 \mathrm{~km})$ than Kinneil $(32-36 \mathrm{~km})$. The reason for this is not known but could presumably be an effect of reduced salinity, poorer food supply due to less organic enrichment, more competition for food or higher predation on Skinflats. The deposit feeder Capitella capitata which was the second most important polychaete species and third most important annelid in terms of biomass on the lower Forth estuary was mainly confined to Kinneil. It is possible that the presence of $C$. capitata on Kinneil reflected a large organic load to this area as the animal is reported to flourish in areas with a high organic input (Reish, 1957; Reish \& Barnard, 1960). However Muus (1967) did not find the animals particularly associated with polluted localities. In this survey $C$. capitata was always associated with other species: usually high densities of $M$. aestuarina and $P$. benedeni. Pygospio elegans occurred sporadically, but generally closer to the low-water mark on Torry Bay where water flow is faster. Muus (1967) observed that this species was not found in areas where water movement was slow.

One important feature of the study was the complete absence of any annelids from stations close to the outfall from the petro-chemical complex at Grangemouth. The only animals observed in these samples were occasional nematodes and a few specimens of a harpacticoid Platychelipus sp. This abiotic zone has been reported in previous surveys of the region (McLusky et al., 1976, 1978). The annelid fauna sampled in this study comprised a mean biomass of $27.97 \mathrm{~g}$ dry $\mathrm{wt} \mathrm{m}^{-2}$ for the Stirling to Kincardine Bridge area, and $6.30 \mathrm{~g}$ dry $\mathrm{wt} \mathrm{m}^{-2}$ for the area below Kincardine Bridge. In the former area oligochaetes are often the sole fauna, but in the latter area they share the mudflats with other macrofauna. Elliott (1979) has recorded the mean macrofaunal biomass of $15.0 \mathrm{~g}$ flesh dry wt $\mathrm{m}^{-2}$ (excluding Oligochaeta and Mytilus) from Torry Bay.

Haka et al. (1974) and Giere (1975) have calculated P:B ratios of 3:1 for oligochaetes and Warwick et al. (1979) assumed that meiofaunal polychaetes have the same $\mathrm{P}: \mathrm{B}$ as a short lived macrofaunal polychaete, Ampharete acutifrons, i. e. 5.5:1. Using these P:B ratios the production of oligochaetes on the upper Forth estuary would be $83.91 \mathrm{~g}$ dry wt $\mathrm{m}^{-2} \mathrm{yr}^{-1}$, and on the lower Forth estuary would be $11.59 \mathrm{~g}$ dry wt $\mathrm{m}^{-2} \mathrm{yr}^{-1}$ for oligochaetes and $13.40 \mathrm{~g}$ dry $\mathrm{wt} \mathrm{m}^{-2} \mathrm{yr}^{-1}$ for small polychaetes. The total production of small worms on the lower Forth estuary of $25 \mathrm{~g}$ dry wt $\mathrm{m}^{-2}$ compares with the production of infaunal macrofauna (principally molluscs) for this area calculated by Elliott (1979) as $20.6 \mathrm{~g}$ flesh dry $\mathrm{wt} \mathrm{m}^{-2} \mathrm{yr}^{-1}$. The estimated total infaunal production of $45.6 \mathrm{~g}$ flesh dry wt $\mathrm{m}^{-2}$ for the Forth estuary compares closely with Wolff \& de Wolf's (1977) estimate of $39.8-32.7 \mathrm{~g}$ for the Grevelingen estuary.

Oligochaetes have been seen to be most abundant in the Forth in areas of organic enrichment (except abiotic zones), and the above mean estimates would be greater in areas of pollution, and less in less polluted zones. Although there may be important seasonal fluctuations in biomass which will alter the production estimates these calculations do suggest that oligochaetes and small polychaetes will be at least as important energetically as the macrofauna of these mudflats. To study this in greater detail a monthly sampling programme has been established at selected stations to examine temporal changes in numbers and biomass of the annelid fauna and to use more precise 
methods to estimate the production of this important portion of the intertidal estuarine fauna, and the impact of pollution upon it.

Acknowledgements. This work was supported in part by the Natural Environment Research Council. It is a pleasure to thank A. Henderson for assistance with oligochaete identification, and K. McKeown for help with sample collection.

\section{LITERATURE CITED}

Brinkhurst, R. O., 1965. Observations on the recovery of a British river from gross organic pollution. - Hydrobiologia 25, 9-51.

Brinkhurst, R. O. \& Baker, H. R., 1979. A review of the marine Tubificidae (Oligochaeta) of North America. - Can. J. Zool. 57, 1553-1569.

Dahl, I. 1960. The oligochaete fauna of three Danish brackishwater areas (Taxonomic and biological observations). - Meddr Danm. Fisk.-og Havunders. 2 (26), 1-20.

Elliott, M., 1979. Studies on the production ecology of several mollusc species in the estuarine Firth of Forth. - Ph. D. Thesis, University of Stirling, $430 \mathrm{pp}$.

Eyres, J. P., Williams, N. V. \& Pugh-Thomas, M., 1978. Ecological studies on Oligochaeta inhabiting depositing substrata in the Irwell, a polluted English river. - Freshwater Biol. 8, 25-32.

Forth River Purification Board, 1978. Annual report 1978, 1-100.

Giere, O., 1975. Population structure, food relations and ecological role of marine oligachaetes within special reference to meiobenthic species. - Mar. Biol. 31, 139-156.

Gray, J. S., 1976. The fauna of the polluted River Tees estuary. - Estuar. coast. mar. Sci. 4, 653-676.

Haka, P., Holopainen, I. J., Ikonen, E., Leisma, A., Paasiverta, L., Saaristo, P., Sarvala, J. \& Sarvala, M., 1974. Paarjarven pohjaelaimiste. - Luonnon Tutk. 78, 157-173.

Hunter, J. \& Arthur, D. R., 1978. Some aspects of the ecology of Peloscolex benedeni Udekem (Oligochaeta: Tubificidae) in the Thames estuary. - Estuar. coast. mar. Sci. 6, 197-208.

Kennedy, C. R., 1965. The distribution and habitat of Limnodrilus hoffmeisteri Claparède (Oligochaeta, Tubificidae). - Oikos 16, 26-28.

Laasko, M., 1969. Oligochaeta from brackish water near Tvarminne, south west Finland. - Ann. zool. Fenn. 6, 98-111.

Leppäkoski, E., 1975. Assessment of degree of pollution on the basis of macrozoobenthos in marine and brackish-water environments. - Acta Acad. åbo. (B) 35 (2), 1-90.

McLusky, D. S., 1979. Ecology of the Forth estuary. - Forth Nat. 3, 10-23.

Mclusky, D. S., Bryant, D., Elliott, M., Teare, M \& Moffat, G., 1976. Intertidal fauna of the industrialised Forth estuary. - Mar. Pollut. Bull. 7, 48-51.

McLusky, D. S., Elliott, M. \& Warnes, J., 1978. The impact of pollution on the intertidal fauna of the estuarine Firth of Forth. In: Physiology and behaviour of marine organisms. Ed. by D. McLusky \& A. Berry. Pergamon Press, Oxford, 203-210.

Muus, B. J., 1967. The fauna of Danish estuaries and lagoons. Distribution and ecology of dominating species in the shallow reaches of the mesohaline zone. - Meddr Danm. Fisk.-og Havunders. 5, 1-316.

Pearson, T. H. \& Rosenberg, R., 1978. Macrobenthic succession in relation to organic enrichment and pollution of the marine environment. - Oceanogr. mar. Biol. 16, 229-311.

Phizacklea, A. P., 1978. The distribution of oligochaete worms on the inner Forth estuary. - B. Sc. Honours Thesis, University of Stirling, $164 \mathrm{pp}$.

Reish, D. J., 1957. The relationship of the polychaetous annelid Capitella capitata (Fabricius) to waste discharges of biological origin. In: Biological problems in water pollution. Ed. by C. M. Tarzwell. U. S. Public Health Service. 195-200.

Reish, D. J. \& Barnard, I. L., 1960. Field toxicity test in marine water utilising the polychaetous annelid Capitella capitata (Fabricius). - Pacif. Nat. 1, 21.

Stczynska-Jurewicz, E., 1972. Fecundity, survival and haemolymph concentration of Physa acuta and Tubifex tubifex in relation to salinity of the external medium. - Polskie Arch. Hydrobiol. 19, 223-234. 
Stout, H. P., 1976. Prediction of oxygen deficits associated with effluent inputs to the Forth estuary. Proc. Instn civil. Engrs. 61,351-366.

Teare, M., 1979. The distribution of oligochaetes and small polychaetes in the intertidal regions of the estuarine Firth of Forth. - Internal Rep. Univ. Stirling, $32 \mathrm{pp.}$

Warwick, R. M., Joint, I. R. \& Radford, P. J., 1979. Secondary production of the benthos in an estuarine environment. In: Ecological processes in coastal environments. Ed. by R. L. Jefferies \& A. J. Davy. Blackwell, Oxford, 429-450.

Wharfe, J. R., 1975. A study of the intertidal macrofauna around the B. P. refinery (Kent) Limited. Environ. Pollut. 9, 1-12.

Wolff, W. J. \& Wolf, L. de, 1977. Biomass and production of zoobenthos in the Grevelingen estuary, The Netherlands. - Estuar. coast. mar. Sci. 5, 1-24. 